\title{
Memahami Teks, Melahirkan Konteks: Menelisik Interpretasi Ideologis Jamaah Tabligh
}

\author{
Didi Junaedi ${ }^{1}$
}

\begin{abstract}
The dialectical process between the Qur'ān, Hadith and other religious texts with reality will produce a variety of interpretations. This diversity of interpretations within different kinds of approaches: theological, legal, mystical, social, political, economical, as well as various other points, in turn will present a discourse in the domain of thought, as well as practical measures in social realities.

In this article, the author analyzes the theological and legal interpretation of Jamā'ah Tabligh. He also discusses a number of concepts which was arisen from their readings of a number of verses in the Qur'ān and Hadith.
\end{abstract}

\begin{abstract}
Abstrak
Proses dialektika antara al-Qur'an, Hadith serta teks-teks keagamaan dengan realitas akan melahirkan beragam penafsiran. Ragam penafsiran dengan berbagai sudut pandang; teologi, hukum (fiqh), tasawuf, sosial, politik, ekonomi, serta pelbagai sudut pandang lainnya tersebut, pada gilirannya akan menghadirkan diskursus dalam ranah pemikiran, serta tindakan praksis dalam realitas sosial. Dalam tulisan ini, penulis akan menyoroti penafsiran teologis dan fiqh oleh Jamaah Tabligh. Ia juga mendiskusikan sejumlah konsep Jamaah Tabligh yang lahir atas pembacaan mereka terhadap sejumlah ayat al-Qur'an dan Hadith.
\end{abstract}

Keywords: Jamaah Tabligh, khurūj, shahādah, ikrām muslimīn.

${ }^{1}$ Dosen Tetap Mata Kuliah Tafsir dan Ilmu al-Qur'ān pada Jurusan Tafsir Hadis Fak. Adab Dakwah dan Ushuluddin (ADDIN) IAIN Syekh Nurjati Cirebon. E-mail: didijunaedi_hz@yahoo.com 


\section{Pendahuluan}

Dinamika penafsiran al-Qur'ān, sejak kitab suci ini diwahyukan kepada Nabi Muhammad saw. sampai saat ini tidak pernah mengalami kemandegan, justru menunjukkan perkembangan yang cukup signifikan. ${ }^{2}$ Hal ini dimungkinkan, karena selain al-Qur'ān layaknya lautan ilmu tak bertepi, juga karena basis al-Qur'ān yang hadir di tengah-tengah kita berbentuk teks.

Ketika sebuah teks hadir ke tengah masyarakat, maka ia telah menjadi milik publik. Publik pun akan memberikan apresiasi dan pemahaman sesuai dengan kadar intelektualitas yang mereka miliki. Dengan demikian, tak pelak, pelbagai interpretasi pun muncul seputar teks tersebut.

Al-Qur'ān, sebagaimana kita yakini merupakan firman Allah Swt, disampaikan oleh Jibril as. kepada Nabi Muhammad saw. dalam bahasa lisan (oral). Nabi Muhammad saw. pun kemudian menyampaikan firman-firman Tuhan tersebut kepada para Sahabat dalam bahasa lisan. Kemudian sebagian sahabat mencatatnya, sebagian lain mengingat atau menghafalnya.

Pada masa selanjutnya, yakni sepeninggal Nabi Muhammad saw., para Sahabat berusaha menghadirkan "pesan-pesan" Tuhan tersebut ke tengah masyarakat dalam bentuk bahasa tulis berupa teks. Hal ini dimaksudkan agar "pesan-pesan" Tuhan tersebut tidak hanya terekam dalam ingatan (hafalan) beberapa orang Sahabat saja, akan tetapi, lebih jauh dapat dinikmati oleh generasi-generasi berikutnya. Dengan demikian, generasi pasca Sahabat dan seterusnya tidak mengalami missing link (keterputusan mata rantai).

Transformasi dari bahasa lisan (oral) menjadi bahasa tulis (teks) pada gilirannya meniscayakan pelbagai konsekuensi. Salah satu konsekuensi yang tidak mungkin dihindari adalah persentuhannya dengan aspek sejarah kemanusiaan. Meskipun kita yakini bahwa teks al-Qur'ān seakan-akan sebagai "penjelmaan" dan "kehadiran" Tuhan, namun bagaimanapun juga begitu memasuki wilayah sejarah, firman tadi terkena batasan-batasan kultural yang berlaku pada dunia manusia. ${ }^{3}$ Dengan demikian, al-Qur'ān pun mengalami 'nasib' yang sama dengan teks-teks lain yang hadir ke tengah publik. Publik

${ }^{2}$ Amīn al-KhūTi, Manāhij Tajdìd fĭ al-Naḥw wa al-Balāghah wa al-Tafsìir wa alAdab (Kairo: Dār al-Ma'rifah, 1961), 302.

${ }^{3}$ Komaruddin Hidayat, Memahami Bahasa Agama; Sebuah Kajian Hermeneutik (Jakarta: Paramadina, 1996), 9. Nașr Hāmid Abū Zaid bahkan menyebut al-Qur'ān sebagai "muntaj thaqāfi" (produk budaya), yakni sebagai teks yang muncul dalam sebuah struktur budaya Arab selama lebih duapuluh tahun dan ditulis dengan berpijak pada aturan-aturan budaya tersebut. Lihat Nașr Ḥāmid Abū Zaid, Mafhūm al-Nașs; Dirāsat fí 'Ulūm al-Qur'ān (Beirūt: al-Markaz al-Thaqāfī al-'Arabī, 1990), 24. 
akan mengapresiasi dan menafsirnya sesuai dengan kadar pemahaman yang mereka miliki.

Pada masa pewahyuan, di mana Nabi saw. saat itu masih berada di tengah masyarakat, segala kesulitan dan ketidakjelasan dalam memahami makna serta kandungan ayat-ayat al-Qur'ān dapat ditanyakan langsung kepada beliau selaku al-mufassir al-awwal (mufassir pertama). Namun setelah Nabi saw. wafat, tidak ada lagi tempat bertanya dan mengadukan segala hal berkaitan dengan kemusykilan dalam memahami al-Qur'ān. Maka, kemudian timbullah perbedaan penafsiran di antara para sahabat dalam memahami maksud ayat-ayat al-Qur'ān, yang memang tidak semua dijelaskan oleh Rasulullah. Perbedaan penafsiran tersebut berlanjut sampai pada masa tābi'in, atbā'al-tābi'īn, atbā' atbā'al-tābi'īn hingga umat Islam dewasa ini.

Singkatnya, dialektika antara al-Qur'ān, Ḥadith serta teks-teks keagamaan dengan realitas akan melahirkan beragam penafsiran. Ragam penafsiran ini pada gilirannya akan menghadirkan wacana (discourse) dalam ranah pemikiran, serta tindakan praksis dalam realitas sosial.

Dalam tulisan ini, selanjutnya penulis akan menguraikan pandangan salah satu kelompok umat Islam yang menamakan dirinya dengan Jama'ah Tabligh, dalam memaknai serta menafsirkan sejumlah ayat al-Qur'ān dan Hadith yang dijadikan sebagai basis dalam berakidah, beribadah, bermu'amalah serta berdakwah.

\section{Latar Belakangan Sejarah}

Jama'ah Tabligh didirikan oleh Syaikh Maulana Muhammad Ilyas (18851944) pada $1920^{4}$ di Desa Kandhla di Wilayah Muzhafar Nagar, Utarpradesh, India. ${ }^{5}$

Sebuah peristiwa yang melatar belakangi lahirnya Jamaah Tabligh ini terjadi pada 1920, yaitu ketika Maulana Muhammad Ilyas melakukan perjalanan ke Mewat, sebuah wilayah yang terletak di Gurgaon selatan Delhi. Setibanya di Mewat, ia menjumpai dan menyaksikan masyarakat Mewat, yang notabene beragama Islam, melakukan praktek penyimpangan ajaran Islam. Bentuk penyimpangan tersebut berupa pencampuradukkan antara ajaran Islam dengan adat Hindu, seperti memohon kepada Dewa Brahmana untuk menentukan

\footnotetext{
${ }^{4}$ Dalam keterangan lain disebutkan tahun 1930. Lihat Azyumardi Azra, "Contemporary Religio-Intellectual Connections Between Indonesia and the Middle East", dalam Johan Meuleman (ed.), Islam In the Era of Glabalization; Muslim Attitudes towards Modernity and Identity (New York: Routledge, 2002), 42.

${ }^{5}$ Abu Hasan Ali al-Nadwi, Maulana Muhammad Ilyas, Terj. Masrokhan Ahmad (Yogyakarta: Ash Shaff, 1990), Cet. II, 5.
} 
tanggal perkawinan mereka, mencampur adukkan Hari Besar Islam dengan Hari Besar Hindu, merayakan upacara-upacara kesucian Hindu, seperti Janam, Ashtani, Dessehra dan Diwali. ${ }^{6}$

Bermula dari keprihatinan Maulana Muhammad Ilyas terhadap pemahaman serta praktek keagamaan masyarakat Mewat inilah, kemudian ia berusaha untuk memperbaiki dan mengembalikan masyarakat Mewat kepada ajaran Islam. Bentuk nyata dari usaha memperbaiki masyarakat Mewat adalah dengan mendirikan Jamaah ---kelak menjadi Jamaah Tabligh--- yang beranggotakan masyarakat Mewat yang telah kembali kepada ajaran Islam.

Konon, pembentukan Jamaah ini diilhami oleh mimpi Maulana Muhammad Ilyas pada suatu malam tentang firman Allah Q.S. Āli 'Imrān: 104 berupa perintah Allah Swt agar memperbaiki kondisi umat manusia. ${ }^{7}$

Q.S. Âli 'Imrān: $104:^{8}$

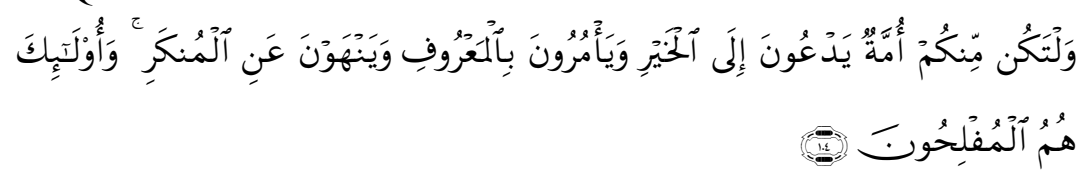

Menurut Mumtaz Ahmad, munculnya gerakan Jama'ah Tabligh ini adalah respon Maulana Muhammad Ilyas atas pelbagai persoalan sosial keagamaan yang terjadi di India ketika itu. Pertama, membangkitkan kembali keimanan dan menegaskan ulang identitas relijius-kultural Muslim. Dalam konteks ini, kelahirannya dapat dikatakan sebagai bentuk ortodoksi Islam yang disegarkan kembali, maupun sebuah sufisme yang diperbaharui. Kedua, kemunculannya juga merupakan tanggapan langsung terhadap gerakan-gerakan pengalihan agama Hindu yang agresif yang dilakukan oleh gerakan Shuddhi (penyucian) dan Sangathan (konsolidasi), yang melancarkan upaya besarbesaran untuk meng-Hindu-kan kembali orang-orang yang telah memeluk Islam pada masa lalu. Ketiga, mengislamkan kembali Muslim "tapal batas" dari praktik-praktik keagamaan dan kebiasaan sosial nenek moyang orang Hindu. ${ }^{9}$

${ }^{6}$ Ali al-Nadwi, Life and Mission of Maulana Mohammad Ilyas (Lucknow: Academy of Islamic Research and Publication, 1983), 25.

${ }^{7}$ Husein bin Muslim bin Ali Jabir, Membentuk Jama'ah Muslimin (Jakarta: Gema Insani Press, 1992), Cet. III, 259.

8 "Dan hendaklah ada di antara kamu segolongan umat yang menyeru kepada kebajikan, menyuruh kepada yang makruf dan mencegah dari yang munkar; merekalah orang-orang yang beruntung. ”(Q.S. Āli 'Imrān: 104).

${ }^{9}$ Lihat Mumtaz Ahmad, "Jama'ah Tabligh," dalam John L. Esposito (ed.), Ensiklopedi Oxford Dunia Islam Modern (Bandung: Mizan, 2001), 35-36. 
Pada mulanya kegiatan yang dipimpin oleh Maulana Muhammad Ilyas ini hanya terkonsentrasi di Mewat, kemudian pada masa-masa selanjutnya kegiatan Jamaah Tabligh berpusat di Masjid Bangle Wali, Nizamuddin, New Delhi. $^{10}$

Pada zamannya, ruang lingkup gerakan ini terbatas di India. Setelah Maulana Muhammad Ilyas meninggal, kepemimpinan diteruskan oleh puteranya, Maulana Muhammad Yusuf al-Kandahlawi (1917-1965). Pada masa inilah, Jama'ah Tabligh mengalami perkembangan yang pesat, yaitu menyebar ke seluruh India, Pakistan, Bangladesh bahkan melintasi pelbagai negara, hingga ke Asia Tenggara, Timur Tengah, Afrika, Eropa hingga Amerika Serikat. ${ }^{11}$

Dalam konteks Indonesia, Jama'ah Tabligh datang pertama kali pada $1952^{12}$ di Medan, dipimpin oleh Miaji Isa dengan menamakan kelompoknya sebagai Jama'ah Khuruj, yakni Jamaah yang keluar di Jalan Allah untuk melatih memperbaiki diri dan mengajak untuk taat kepada Allah. Akan tetapi, gerakan ini baru menampakkan kegiatannya yang intensif pada 1970-an, tepatnya ketika pada 1974 dibangun Masjid Jami' Kebon Jeruk, Jakarta, sebagai pusat (markaz) kegiatan serta gerakan Jama'ah Tabligh tingkat nasional.

\section{Prinsip, Sumber Ajaran dan Metode Dakwah}

Prinsip dakwah Jama'ah Tabligh adalah al-amr bi al-ma'rüf wa al-nahy 'an al-munkar demi membawa kesuksesan dan kejayaan umat manusia baik di dunia maupun di akhirat. ${ }^{13}$ Adapun sumber ajaran dari gerakan Jama'ah Tabligh adalah al-Qur'ān dan al-Sunnah. Dengan demikian, tidak ada perbedaan yang prinsip antara gerakan Jama'ah Tabligh dengan umat Islam pada umumnya. Kitab-kitab yang digunakan adalah karangan para ulama salaf, seperti: Riyaḍ al-Sāliḥin, Ihya 'Ulūm al-Dīn, Fatḥ al-Mu'īn dan semua kitab tafsir.

Selain menggunakan beberapa kitab rujukan sunni di atas, Jama'ah Tabligh juga memiliki buku pegangan standar bagi pengikutnya, yaitu Kitab

\footnotetext{
${ }^{10}$ Muhammad Khalid Masud (ed.), Travellers in Faith; Studies of the Tablighi Jama'at as a Transnational Islamic Movement for Faith Renewal (Leiden: Brill, 2000), vii.

${ }^{11}$ Keterangan lebih lanjut, lihat M. Anwarul Haq, The Faith Movement of Maulana Muhammad Ilyas (London: George Allen \& Unwin Ltd., 1972).

${ }^{12}$ Abdul Aziz, "The Jamaah Tabligh Movement in Indonesia," Studia Islamika 11:3, (2004), 478. Bandingkan dengan Azyumardi Azra, "Contemporary Religio Intellectual Connections Between Indonesia and the Middle East", dalam Johan Meuleman (ed.), Islam In the Era of Glabalization; Muslim Attitudes towards Modernity and Identity, 42.

${ }^{13}$ Nadhr M. Ishak Shahab, Khurūj fí Sabīlillāh (Bandung: Pustaka Billah, tt), 15.
} 
Fậầil al-A'māl atau disebut juga dengan Tabligh al-Niṣāb, karya Mawlana Muhammad Zakariya al-Kandahlawi. Kitab ini mulanya berbahasa Urdu dan sudah diterjemahkan ke dalam bahasa Indonesia. ${ }^{14}$ Kitab ini berisi tujuh keutamaan, yaitu: keutamaan al-Qur'ān, keutamaan shalat, keutamaan dzikir, keutamaan tabligh, hikayat para sahabat, kemerosotan umat dan keutamaan ramadhan. $^{15}$

Kitab lain yang juga dijadikan pegangan standar bagi para pengikut Jama'ah Tabligh ini adalah Hayāt al-Ṣahābah, karya Mawlana Yūsuf alKandahlawi, putra Maulana Muhammad Ilyas, serta Muntakhab Ahàdith, yang juga merupakan karya Maulana Yūsuf al-Kandahlawi yang disusun kembali oleh Maulana Sa'ad al-Kandahlawi. ${ }^{16}$

Dalam kitab Muntakhab Ahädith inilah dijelaskan secara detail enam prinsip (ajaran) gerakan Jama'ah Tabligh, yang kemudian mereka sebut dengan "enam sifat sahabat". ${ }^{17}$ Keenam prinsip tersebut adalah: Pertama, mewujudkan hakekat syahadat; Kedua, shalat; Ketiga, ilmu disertai dzikir; Keempat, memuliakan sesama muslim; Kelima, ikhlas beramal (meluruskan niat); dan Keenam, dakwah dan tabligh di jalan Allah. ${ }^{18}$ Keenam prinsip tersebut juga merupakan metode dakwah yang dikembangkan oleh Jama'ah Tabligh. Bahkan, mereka mengklaim bahwa enam prinsip yang dikenal sebagai "enam sifat sahabat" ini merupakan cara yang paling mudah dan ringkas untuk mendeskripsikan seluruh ajaran Islam. ${ }^{19}$

\section{Mengurai Enam Prinsip Dasar Jama'ah Tabligh}

Dalam bagian ini, penulis berusaha menguraikan secara singkat keenam prinsip dasar gerakan Jamaah Tabligh disertai argumen teologis yang mereka bangun berdasarkan al-Qur'ān dan Hadīth .

Perlu ditegaskan di sini, bahwa apa yang penulis uraikan nanti adalah hasil pembacaan penulis atas pemahaman mereka terhadap sejumlah ayat alQur'ān dan Hadith, yang mereka jadikan sebagai basis argumennya. Terlepas

\footnotetext{
${ }^{14}$ Dalam edisi Bahasa Indonesia diterjemahkan oleh Maulana Muhammad Shidiq dan Maulana Tirmizi Abdillah, diterbitkan oleh Pustaka Ramadhan, Bandung.

${ }^{15}$ Maulana Muhammad Zakariya al-Kandahlawi, Himpunan Fadhilah Amal (Bandung: Pustaka Ramadhan, tt.), 4.

${ }^{16}$ Maulana Muhammad Yusuf al-Kandahlawi, Muntakhab Ahādith (Yogyakarta: Penerbit Ash-Shaf, 2007)

${ }^{17}$ Maulana Muhammad Yusuf al-Kandahlawi, Muntakhab Ahāoitith, 2.

${ }^{18}$ Maulana Wahiduddin Khan, Tabligh Movement (Delhi: Islamic Center, 1994), 24.

${ }^{19}$ Lihat Yusron Razak, "Jamaah Tabligh: Ajaran dan Dakwahnya" (Disertasi UIN Jakarta: 2008), 89.
} 
apakah pemahaman mereka bersifat tekstual ataukah kontekstual, penulis serahkan kepada bagaimana kita (pembaca) melihat sesuai dengan persepsi kita masing-masing.

\section{Hakekat Syahadat}

Syahadat dalam perspektif Jama'ah Tabligh adalah persaksian dan pengakuan kepada Allah Swt, sebagai satu-satunya Tuhan yang wajib disembah, serta persaksian dan pengakuan bahwa Muhammad saw adalah Rasulullah. Syahadat harus diyakini dalam hati, diucapkan dengan lidah dan didengar dengan telinga, agar seseorang benar-benar merasa sebagai hamba Allah dan pengikut Rasulullah. ${ }^{20}$

Untuk mendapat keimanan yang sempurna, seseorang harus mencapai hakekat là ilāha illa Allāh dengan cara: pertama, selalu mendakwahkan pentingnya iman; kedua, latihan dengan cara membentuk halaqah iman; dan ketiga, berdoa kepada Allah agar dikaruniai hakikat iman. ${ }^{21}$

Selain ketiga syarat di atas, untuk mendapatkan hakekat keimanan, seseorang harus mempercayai bahwa Allah menciptakan segala sesuatu dengan melibatkan hukum sebab-akibat (kausalitas). Dalam pandangan Jama'ah Tabligh, hukum kausalitas terbagi menjadi tiga: Pertama, asbāb zulumāt, yaitu kemampuan Allah mengubah sesuatu yang tidak pasti; Kedua, asbāb fitrah, yaitu kemampuan Allah mengubah asbāb hukum alam (sunnatullah), sebagaimana Allah mampu mengubah sifat panas api; Ketiga, asbāb mutlaq, yaitu Allah tidak mengubah $a s b \bar{a} b$ agama ini. ${ }^{22}$

Argumen yang dikemukakan oleh Jama'ah Tabligh tentang kewajiban penyerahan diri, berupa keimanan yang sempurna disertai ketaatan mutlak atas qudrat dan iradat Allah adalah Q.S. al-Nisā: $59:^{23}$

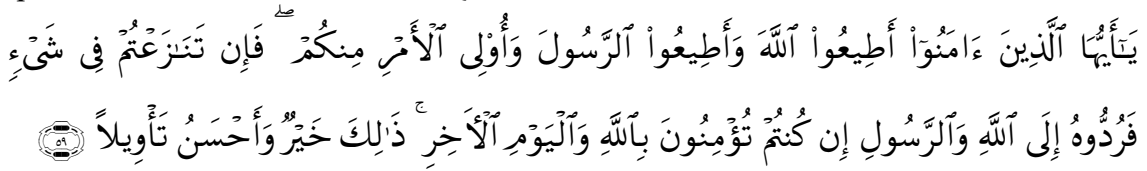

\footnotetext{
${ }^{20}$ Furqan Ahmad, Pedoman Bertabligh, 17.

${ }^{21}$ Maulana Muhammad Yusuf al-Kandahlawi, Enam Sifat Para Sahabat dan Amalan Nurani (Bandung: Pustaka Ramadhan, 2006), 5.

${ }^{22}$ Nadhar M. Ishak Shahab, Khurūj fi Sabīlillāh, 7.

23 "Hai orang-orang yang beriman, taatilah Allah dan taatilah Rasul (Nya), dan ulil amri di antara kamu. Kemudian jika kamu berlainan pendapat tentang sesuatu, maka kembalikanlah ia kepada Allah (Al Qur'an) dan Rasul (sunnahnya), jika kamu benarbenar beriman kepada Allah dan hari kemudian. Yang demikian itu lebih utama (bagimu) dan lebih baik akibatnya."(Q.S. al-Nisā: 59)
} 
Adapun Hadits yang sering dijadikan argumen oleh Jama'ah Tabligh tentang pentingnya pengucapan kalimat lā ilāha illa Allāh adalah sebuah riwayat dari Abu Hurairah bahwa Rasulullah Saw bersabda: "Iman itu mempunyai enam puluh enam atau tujuh puluh tujuh cabang, yang paling utama adalah kalimat là ilāha illa Allāh dan yang terendah adalah membuang duri (sesuatu yang mengganggu) dari jalan. Dan malu adalah cabang dari iman." ${ }^{24}$

Pada prinsipnya, pemahaman terhadap konsep syahadat Jamaah Tabligh sama dengan pemahaman umat Islam pada umumnya, yaitu mengakui dan meyakini sepenuh hati, bahwa hanya Allah Tuhan yang patut disembah, ditaati serta sebagai Dzat di mana kita meminta pertolongan dan perlindungan. Selanjutnya, pengakuan bahwa Nabi Muhammad saw. adalah utusan Allah, yang kepadanya diberikan petunjuk hidup umat manusia yang bernama alQur'ān. Dan dialah Nabi akhir zaman serta penutup para Nabi.

Dalam konsepsi Jamaah Tabligh, pengakuan akan eksistensi ketuhanan dan kenabian ini merupakan satu paket utuh yang tidak dapat dipisahkan satu sama lain. Pengingkaran terhadap salah satunya, lebih-lebih terhadap keduanya menjadikan seseorang kafir, dan bagi mereka kesengsaraan di akhirat nanti.

\section{Shalat dengan Khushū' dan Khudū',}

Dalam pandangan Maulana Muhammad Ilyas, shalat merupakan pintu menuju seluruh amal shalih dan memiliki makna yang sangat dalam. Shalat mengajarkan sikap tawaduk atau rendah hati. Adapun menurut Maulana In'amul Hasan, shalat merupakan sarana untuk memperbaiki hubungan ubudiyah antara seorang manusia dengan Allah. ${ }^{25}$

Shalat khush $\bar{u}$ ' dan khudū' merupakan prinsip ajaran kedua Jama'ah Tabligh. Shalat khushü, adalah hubungan langsung antara seorang hamba dengan Khalik, yang dilakukan dengan penuh konsentrasi pikiran, hati dan perasaan serta seluruh anggota badan terpusat (tawajjuh) kepada Allah Swt. Sedangkan shalat khudu ' adalah shalat yang dilakukan dengan kerendahan hati dan diri sebagai tanda kepatuhan terhadap kebesaran Allah Swt, dilakukan dengan tenang tidak melakukan gerakan lain selain yang diperintahkan dalam rukun dan tertibnya, yaitu pada awal waktu di tempat adzan dikumandangkan dengan cara berjamaah. ${ }^{26}$

${ }^{24}$ Lihat dalam Abū 'Abd Allāh Muhammad Ibn Ismā'ìl Ibn Ibrāhīm Ibn alMughīrah Ibn Bardizbah al-Bukhāīi, Șahīh al-Bukhārī, Juz I, 10.

${ }^{25}$ Muhammad bin 'Aqil "Abdullah Dahlan al-Jailani, Mudzakarah 6 Sifat (Bintaro: Yayasan Hayatur Rasul, tt.), 7.

${ }^{26}$ Nadhar M. Ishak Shahab, Khurūj fi Sabìillāh, 41. 
Dalil yang dikemukakan Jama'ah Tabligh tentang hal ini adalah Q.S. alMā'ūn: 4-6: ${ }^{27}$

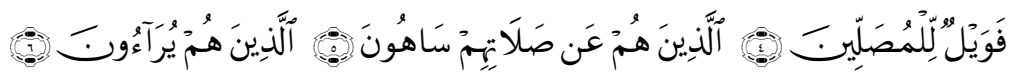

Jama'ah Tabligh memaknai ayat ini dengan menyatakan bahwa orangorang yang shalat, sedangkan di dalam dirinya tidak ada keikhlasan, maka balasannya tidak lain adalah wail, celaka.

Adapun dalil dari Hadits (Qudsi) yang cukup populer di kalangan mereka adalah yang menyatakan, Rasulullah saw bersabda: Allah Swt berfirman: “ Sesungguhnya Aku mewajibkan umatmu shalat lima waktu. Dan Aku telah bersumpah pada diri-Ku, bahwa barangsiapa yang datang (pada hari kiamat) sedang ia menjaga shalat yang lima ini tepat pada waktunya, niscaya aku akan memasukkannya ke dalam surga. Dan barangsiapa yang tidak menjaga shalat yang lima ini, maka tidak ada perjanjian baginya dari sisi-Ku. ${ }^{{ }_{2} 8}$

Jama'ah tabligh meyakini bahwa setiap muslim yang dapat melaksanakan shalat di awal waktu, secara berjamaah dengan penuh kekhusyu'an akan diberikan jaminan berupa rezeki yang barakah, terbebas dari azab kubur, menerima catatan amal dengan tangan kanan, melintasi jembatan secepat kilat, serta masuk surga tanpa hisab. ${ }^{29}$

Satu hal yang patut kita hargai dari semangat dan usaha Jama'ah Tabligh berkaitan dengan masalah shalat lima waktu ini adalah, bahwa mereka selalu berusaha menjalankan shalat lima waktu di awal waktu, dan dilakukan secara berjamaah.

Menjalankan shalat lima waktu di awal waktu dan dilakukan secara berjamaah, seolah menjadi 'trade mark' dari gerakan Jamaah Tabligh. Mereka begitu concern mengajak umat Islam untuk melakukan kegiatan ibadah yang satu ini sebagaimana yang mereka jalankan. Mereka rela berdakwah door to door, dengan mendatangi satu persatu rumah umat Islam di tempat mereka berdakwah untuk mengajak shalat berjamaah di Masjid.

\section{Ilmu dan Dzikir}

Ilmu dalam pandangan Jama'ah Tabligh terbagi menjadi dua, yaitu 'Ilm al-Faḍā'il dan 'Ilm al-Masā'il. 'Ilm al-Faḍā'il dapat kita peroleh dengan cara duduk dalam majelis taklim yang di dalamnya dibacakan kitab Faḍa'il al-A'māl,

\footnotetext{
27 "Maka celakalah orang yang shalat, (yaitu) orang-orang yang lalai terhadap salatnya, yang berbuat ria.”(Q.S. al-Mā'ūn: 4-6)

${ }^{28}$ Lihat Abu Dawud, Sunan Abī Dāwud (Beirūt: Dār al-Fikr, 1994), Juz I, 114.

${ }^{29}$ Nadhar M. Ishak Shahab, Khurūj fi Sabìilillāh, 71.
} 
sedangkan 'Ilm al-Masā'il dapat diperoleh dengan cara bertanya kepada guru, ustadz atau alim ulama. ${ }^{30}$

Menurut Maulana Muhammad Yusuf, yang dimaksud ilmu adalah mempelajari dan membenarkan hal-hal yang diperintahkan Allah, kemudian mengamalkannya. ${ }^{31}$ Adapun keterkaitan antara ilmu dan dzikir menurut pandangan Jama'ah Tabligh adalah ibarat jalan dan cahaya. Ilmu adalah jalan, dzikir adalah cahaya. Jika seseorang berjalan di dalam kegelapan tanpa ada cahaya, maka ia akan tersesat. Zikir tanpa ilmu juga sesat. ${ }^{32}$

Dalil yang digunakan Jama'ah Tabligh berkaitan dengan ilmu adalah Q.S. al-Mujādalah: 11, “Allah akan mengangkat orang-orang yang beriman di antara kalian dan orang-orang yang berilmu beberapa derajat."

Adapun hadits yang dijadikan dasar pandangan mereka adalah yang menyatakan, "Barangsiapa menempuh jalan untuk menuntut ilmu, maka Allah akan memudahkan jalan baginya menuju surga." 33

Dalil-dalil yang digunakan Jama'ah Tabligh tentang keutamaan dzikir antara lain Q.S. Âli 'Imrān: 41, al-A'raf: 55, al-Anfāl: 2, al-Isrā': 110 dan ayatayat lainnya yang mengandung perintah serta keutamaan dzikir. Misalnya:

Q.S al-Isrā': 110: “ Katakanlah: "Serulah Allah atau serulah Ar-Rahman. Dengan nama yang mana saja kamu seru, Dia mempunyai al asmaaul husna (nama-nama yang terbaik) dan janganlah kamu mengeraskan suaramu dalam salatmu dan janganlah pula merendahkannya dan carilah jalan tengah di antara kedua itu."

Dalam Jamaah Tabligh terdapat dzikir-dzikir umum dan dzikir-dzikir khusus. Dzikir-dzikir umum adalah kalimat thayibah, shalawat dan istighfar, sedangkan dzikir khusus bagi mereka yang dianggap layak mengamalkannya. ${ }^{34}$ Adapun cara berdzikir yang diajarkan oleh Maulana Muhammad Ilyas adalah dengan menggerakkan kepala. ${ }^{35}$

${ }^{30}$ Maulana Muhammad Mansur, Masturah: Usaha Dakwah di Kalangan Wanita (Bandung: Pustaka Ramadhan, 2001), 31.

${ }^{31}$ Furqan Ahmad Anshari, Pedoman Bertabligh Bagi Umat Islam (Yogyakarta: Penerbit Ash-Shaff, 2000), 30.

${ }^{32}$ Lihat Yusron Rozak, "Jamaah Tabligh: Ajaran dan Dakwahnya," 99.

${ }^{33}$ Muslim Ibn al-Hajjaj, Sahịh Muslim , Juz II, 474.

${ }^{34}$ Abdul Rahman Haji Abdullah, Pemikiran Islam di Malaysia; Sejarah dan Aliran (Jakarta: GIP, t.t.), 79.

${ }^{35}$ Syaikh Hakim Moinuddin Chisti, The Book of Sufi Healing, (New York: Inner Traditions International Ltd., 1985), 144-145. 


\section{Memuliakan Orang Islam}

Memuliakan orang Islam (Ikräm al-Musliminn) dalam pandangan Jama'ah Tabligh adalah mengangkat harga dirinya, memberi rasa aman bagi setiap muslim, menjauhkan dari gangguan, serta membantu sesuai dengan kemampuan. ${ }^{36}$

Menurut Maulana Muhammad Ilyas, ikrām al-muslimīn adalah usaha untuk memenuhi hak-hak. ${ }^{37}$ Adapun hak-hak yang wajib dijaga di antara sesama muslim antara lain: Pertama, hak untuk mendapat perlindungan harta, memberikan rasa aman terhadap harta milik orang lain, memberi serta menyisihkan sebagian harta untuk kepentingan bersama; Kedua, hak mendapat perlakuan baik, tidak mencela dan mencaci maki sesama muslim, komitmen terhadap diri sendiri untuk tetap mendoakan saudaranya sampai akhir hayatnya; Ketiga, hak memberi kemudahan, menganjurkan kebaikan serta menjauhkan kemungkaran.

Dalil yang menjadi hujjah pandangan Jama'ah Tabligh tentang konsep ikrām al-muslimīn adalah Q.S. al-Ḥujurāt: 10-13 yang secara tegas menyatakan bahwa sesama mukmin itu bersaudara. Karenanya, harus saling menghormati, berprasangka baik, tidak menggunjing, serta menjauhkan diri dari perbuatan zalim.

Q.S. al-Ḥujurāt: 10-13: "Sesungguhnya orang-orang mukmin adalah bersaudara karena itu damaikanlah antara kedua saudaramu dan bertakwalah kepada Allah supaya kamu mendapat rahmat. Hai orang-orang yang beriman janganlah suatu kaum mengolok-olok kaum yang lain (karena) boleh jadi mereka (yang diolok-olok) lebih baik dari mereka (yang mengolok-olok) dan jangan pula wanita-wanita (mengolok-olok) wanita-Wanita lain (karena) boleh jadi wanita-Wanita (yang diperolok-olokkan) lebih baik dari wanita (yang mengolok-olok) dan janganlah kamu mencela dirimu sendiri dan janganlah kamu panggil memanggil dengan gelar-gelar yang buruk. Seburuk-buruk panggilan ialah (panggilan) yang buruk sesudah iman dan barang siapa yang tidak bertobat, maka mereka itulah orang-orang yang lalim. Hai orang-orang yang beriman, jauhilah kebanyakan dari prasangka, sesungguhnya sebagian prasangka itu adalah dosa dan janganlah kamu mencari-cari kesalahan orang lain dan janganlah sebahagian kamu menggunjing sebahagian yang lain. Sukakah salah seorang di antara kamu memakan daging saudaranya yang sudah

\footnotetext{
${ }^{36}$ Ghulam Musthafa Hasan, Jilāl al-Adhhān, Terj. Ahmad Najib Mahfudz (Yogyakarta: Ash-Shaff, 1997), Cet. II, 9.

${ }^{37}$ Muhammad bin 'Aqil Abdullah Dahlan al-Jailani, Mudzakarah 6 Sifat, 8.
} 
mati? Maka tentulah kamu merasa jijik kepadanya. Dan bertakwalah kepada Allah. Sesungguhnya Allah Maha Penerima tobat lagi Maha Penyayang. Hai manusia, sesungguhnya Kami menciptakan kamu dari seorang laki-laki dan seorang perempuan dan menjadikan kamu berbangsa-bangsa dan bersuku-suku supaya kamu saling kenal mengenal. Sesungguhnya orang yang paling mulia di antara kamu di sisi Allah ialah orang yang paling bertakwa di antara kamu. Sesungguhnya Allah Maha Mengetahui lagi Maha Mengenal."

Sikap menghormati terhadap sesama Muslim ditunjukkan dengan baik oleh gerakan Jamaah Tabligh ini. Mereka tidak mempermasalahkan perbedaan madzhab fiqh yang dianut serta diyakini oleh orang lain di luar Jamaah Tabligh. Mereka tidak pernah menyinggung masalah khilafiyah, perbedaan pemahaman dalam pelaksanaan ibadah ritual. Bagi mereka, yang terpenting adalah bagaimana umat Islam menjalankan ajarannya dengan baik.

Di tempat mereka berdakwah, mereka menunjukkan sikap simpatik terhadap sesama umat Islam. Sekat-sekat madzhab dan organisasi seolah hilang, dan tidak menjadi persoalan bagi mereka.

Satu hal lagi, yang menjadi ciri khas sikap mereka dalam berdakwah, yaitu bahwa mereka murni menjalankan misi dakwah amar makruf nahi munkar. Mereka tidak mau terlibat bahkan anti terhadap dunia politik. Gerakan Jamaah Tabligh adalah gerakan yang tidak mau bersinggungan dengan masalah politik.

\section{Meluruskan Niat}

Muhammad Zakariyya al-Kandahlawi menyatakan bahwa Allah Swt akan memberikan pahala yang besar bagi amal shalih yang dilakukan dengan ketulusan niat (ikhlas), meskipun amalan ringan. Sebaliknya, amal shalih tanpa disertai keikhlasan tidak akan berpengaruh apa-apa baik di dunia maupun di akhirat. Hal ini seperti yang dikatakan Nabi Saw bahwa makna hakikat iman adalah ikhlas. ${ }^{38}$

Landasan teologis yang sering dijadikan dalil Jama'ah Tabligh tentang hal ini adalah Q.S. al-Bayyinah: 5, "Padahal mereka tidak disuruh kecuali untuk menyembah Allah dengan ikhlas dalam (menjalankan) agama."

Makna ikhlas dalam perspektif Jama'ah Tabligh adalah kelurusan, memperbaiki dan membersihkan niat dari awal, pada saat dan setelah melakukan suatu perbuatan. ${ }^{39}$

\footnotetext{
${ }^{38}$ Muhammad Zakaria al-Kandahlawi, Himpunan Fadhilah Amal (Yogyakarta: Ash-Shaff, 2003), 343.

${ }^{39}$ Nadhar M. Ishak Shahab, Khurūj fí Sabīlillāh, 49.
} 
Adapun landasan hadits yang dijadikan rujukan adalah hadis yang cukup populer, diriwayatkan dari 'Alqamah Ibn Waqqāṣ al-Laithi, ia berkata: Aku mendengar Amīr al-Mukminīn 'Umar Ibn al-Khaț̣āb r.a. berkata di atas mimbar: Saya telah mendengar Rasulullah saw bersabda: "Sesungguhnya amal perbuatan itu (tergantung) pada niatnya. Dan sesungguhnya bagi setiap orang itu (akan mendapat balasan) sebagaimana yang diniatkan. Barangsiapa yang berhijrah karena untuk keuntungan dunia yang ingin ia peroleh, atau karena wanita yang ingin ia nikahi, maka hijrahnya itu tergantung kepada niatnya." (HR. al-Bukhari).

Maksud dari ajaran ketulusan niat dalam pandangan Jama'ah Tabligh adalah, agar:

1. Allah Swt menerima segala amal yang dilakukan

2. Setiap amal yang dilakukan selalu tawajjuh kepada Allah Swt bebas dari riya, sum' ah dan bangga diri.

3. Dalam setiap amal yang dilakukan dapat menghidupkan agama yang sempurna di dalam diri dan seluruh alam hingga hari kiamat kelak. ${ }^{40}$

\section{Dakwah dan Tabligh}

Salah satu yang sangat menonjol dalam kegiatan Gerakan Jama'ah Tabligh adalah konsep mengenai dakwah dan tabligh yang mereka pahami. Bagi Jama'ah Tabligh, pergi ke luar untuk kepentingan dakwah diistilahkan dengan “khurüj”, atau "khurūj fî sabillillāh (secara literal berarti keluar di jalan Allah).

Istilah "khurūj", atau "khurūj fï sabīlillāh ini terambil dari kata-kata "ukhrijat" dalam Q.S. Āli 'Imrān: 110, ${ }^{41}$ dan “yakhruj” dalam Q.S. al-Nisā': $100,{ }^{42}$ yang menjadi dalil utama mengenai kewajiban khurüj. Selain itu juga mereka menjadikan Q.S. al-“Aṣr: 1-3, Q.S. Fuṣsilat: 33, Q.S. al-Ṣaff: 14 dan Āli 'Imrān: 104 sebagai dalil tentang perintah berdakwah di jalan Allah.

Q.S. al-'Așr: 1-3: "Demi masa, Sesungguhnya manusia itu benar-benar berada dalam kerugian, kecuali orang-orang yang beriman dan mengerjakan

${ }^{40}$ Sa' ad bin Ibrahim Syilbi, Dalil-dalil Dakwah dan Tabligh (Bandung: Pustaka Ramadhan, 2004), 116.

${ }^{41}$ Ayat ini menyebutkan, "Kalian adalah sebaik-baik umat yang dikeluarkan (ukhrijat) untuk manusia, menyeru kepada yang makruf dan mencegah yang munkar, dan kamu beriman kepada Allah."

${ }^{42}$ Ayat ini menyatakan, "Barangsiapa berhijrah di jalan Allah (fi sabilillah), niscaya mereka mendapati di muka bumi ini tempat hijrah yang luas dan rezeki yang banyak. Barang siapa keluar (yakhruj) dari rumahnya dengan maksud berhijrah kepada Allah dan Rasul-Nya, kemudian kematian menimpanya (sebelum sampai ke tempat yang dituju), maka sungguh telah tetap pahalanya di sisi Allah. Dan Allah Maha Pengampun lagi Maha Penyayang. 
amal saleh dan nasihat menasihati supaya menaati kebenaran dan nasihat menasihati supaya menetapi kesabaran."

Q.S. Āli 'Imrān: 104: "Dan hendaklah ada di antara kamu segolongan umat yang menyeru kepada kebajikan, menyuruh kepada yang makruf dan mencegah dari yang munkar; merekalah orang-orang yang beruntung."

Adapun hadits yang dijadikan basis argumen mereka adalah sebuah riwayat dari Anas r.a, bahwa Rasulullah saw bersabda, "Sesungguhnya sepagi atau sepetang di jalan Allah lebih baik dari dunia seisinya. ${ }^{43}$

Aktivitas dakwah yang dilakukan Jama'ah Tabligh adalah dengan cara berkeliling dari satu tempat ke tempat lain. Aktivitas ini disebut dengan istilah jaulah. Jaulah adalah istilah khas Jama'ah Tabligh untuk mendakwahkan Islam dengan cara berkeliling dari rumah ke rumah untuk dakwah dan silaturahmi. ${ }^{44}$ Menurut pandangan mereka, jaulah adalah metode Rasulullah saw dalam menyebarkan Islam periode Makkah dengan mendatangi kabilah-kabilah yang datang pada musim ziarah.

Di antara dalil yang mereka jadikan landasan adalah Q.S. Yāsin: 13-17: "Dan buatlah bagi mereka suatu perumpamaan, yaitu penduduk suatu negeri ketika utusan-utusan datang kepada mereka; (yaitu) ketika Kami mengutus kepada mereka dua orang utusan, lalu mereka mendustakan keduanya; kemudian Kami kuatkan dengan (utusan) yang ketiga, maka ketiga utusan itu berkata: "Sesungguhnya kami adalah orang-orang yang diutus kepadamu". Mereka menjawab: "Kamu tidak lain hanyalah manusia seperti kami dan Allah Yang Maha Pemurah tidak menurunkan sesuatu pun, kamu tidak lain hanyalah pendusta belaka". Mereka berkata: "Tuhan kami mengetahui bahwa sesungguhnya kami adalah orang yang diutus kepada kamu. Dan kewajiban kami tidak lain hanyalah menyampaikan (perintah Allah) dengan jelas".

Dengan berdasarkan kepada dalil-dalil di atas, maka Gerakan Jamaah Tabligh meyakini sebuah prinsip dasar dalam berdakwah, yaitu harus keluar dari kampung halamannya menuju ke daerah-daerah lain. Mereka menganggap bahwa orang yang belum melakukan khuruj, dakwahnya belum sempurna. Karena itu, dalam gerakan Jamaah Tabligh ada istilah khuruj selama tiga hari, sepuluh hari, empat puluh hari bahkan sampai berbulan-bulan.

\section{Beberapa Catatan Penulis}

Setelah penulis menguraikan secara singkat sejarah munculnya Jama'ah Tabligh, prinsip, ajaran serta metode dakwahnya, perkenankan penulis

\footnotetext{
${ }^{43}$ Al-Bukhārì, Șahịh al-Bukhārì , Juz II, 163.

${ }^{44}$ Nadhar M. Ishak Shahab, Khurūj fi Sabīillāh, 71.
} 
memberikan beberapa catatan yang penulis anggap penting untuk kita diskusikan dan kaji lebih lanjut berkaitan dengan Jama'ah Tabligh.

Pertama, sebagai gerakan dakwah Islam, yang lahir sebagai respon atas pemahaman terhadap realitas dipadu dengan pemaknaan terhadap teks-teks keagamaan, Jama'ah Tabligh patut kita apresiasi.

Kedua, dari hasil pembacaan penulis terhadap model pemahaman Jama'ah Tabligh terhadap sejumlah ayat al-Qur'ān dan Hadits yang dijadikan basis argumennya, dapat dikatakan bahwa dalam memahami teks-teks keagamaan tersebut, Jama'ah Tabligh lebih melihat pada aspek literal-tekstual, daripada makna substantif-kontekstual. Dengan kata lain, subyektivitas penafsiran mereka lebih terlihat, daripada obyektivitasnya.

Hal ini dapat dilihat bagaimana mereka memaknai model dakwah Rasulullah dengan praktek jaulah atau khuruj-nya. Mereka juga berusaha melakukan imitasi dalam aspek sürah (tampilan fisik), seperti mengenakan gamis, memanjangkan jenggot, memakai kopiah khas masyarakat Arab ketika itu, dan juga sirah (perilaku atau tindakan) Rasulullah saw dalam kehidupan sehari-hari, seperti makan dengan menggunakan tangan, secara bersama-sama dengan satu nampan, selalu membawa siwak ke mana pun mereka pergi, dan beragam tindakan yang menurut mereka menjadi sunnah Nabi saw.

Ketiga, dalam akidah, bisa dikatakan Jama'ah Tabligh menganut paham sunni-asy'ari. Dalam fiqh, meski awalnya, pendiri Jama'ah Tabligh adalah bermadzhab Hanafi, namun cenderung lebih toleran terhadap perbedaan madzhab. Mereka tidak pernah mempertentangkan khilafiah. Adapun dalam praktek keagamaannya, mereka lebih kepada ajaran tasawuf amali-akhlaqi. Dalam ranah sosial, mereka layaknya umat Islam pada umumnya, bergaul dengan siapa saja dan tidak menunjukkan kesan eksklusif. Sedangkan dalam ranah politik, mereka tidak mau ikut campur, bahkan cenderung apatis. Dalam ranah ekonomi, mereka menganggap bahwa sistem ekonomi saat ini adalah sistem ekonomi ribawi. Mereka menekankan kepada anggota Jama'ah Tabligh untuk mencari nafkah di sektor pertanian yang menurut mereka lebih bisa terhindar dari praktek ribawi.

Keempat, meski ada kalangan yang mengkritik secara keras terhadap praktek dakwah Jama'ah Tabligh ini, seperti yang dilakukan oleh kelompok salafi-wahabi, sebagaimana tercermin dalam buku yang ditulis oleh Muhammad Taqiyuddin al-Hilali a-Husaini, Sirāj al-Munìr fï Tanbīhi Jama'at al-Tabligh 'alā Akhtaihim, tetapi bagi penulis kehadiran mereka adalah aset bagi perkembangan dakwah Islam di dunia ini. 


\section{Penutup}

Penulis sadar sepenuhnya bahwa tulisan singkat nan sederhana ini, jauh dari sempurna, apalagi untuk memenuhi dahaga intelektual pembaca, jelas jauh panggang dari api.

Namun demikian, penulis berharap setitik informasi ini dapat sekedar membuka mata kita untuk kemudian berusaha mengenal dan mengkaji lebih lanjut fenomena gerakan dakwah yang hadir di tengah-tengah kita.

Dengan demikian, kita tidak buru-buru melontarkan vonis terhadap suatu gerakan yang lahir atas pembacaan terhadap realitas sosial yang dipadu dengan pemahaman terhadap teks-teks keagamaan.

\section{Daftar Pustaka}

Abu Dawud, Sunan Abī Dāwud. Beirūt: Dār al-Fikr, 1994. Juz I.

Abū Zaid, Naṣr Ḥāmid. Mafhūm al-Nașș; Dirāsat fì 'Ulūm al-Qur'ān. Beirūt: alMarkaz al-Thaqāfī al-'Arabī, 1990.

Ahmad, Mumtaz. “Jama'ah Tabligh.” Dalam John L. Esposito (ed.). Ensiklopedi Oxford Dunia Islam Modern. Bandung: Mizan, 2001.

Anshari, Furqan Ahmad. Pedoman Bertabligh Bagi Umat Islam. Yogyakarta: Penerbit Ash-Shaff, 2000.

Aziz, Abdul. "The Jamaah Tabligh Movement in Indonesia." Studia Islamika 11:3, (2004).

Al-Bukhāri, Saḥịh al-Bukhārī, Juz I

Haq, M. Anwarul. The Faith Movement of Maulana Muhammad Ilyas. London: George Allen \& Unwin Ltd., 1972.

Hasan, Ghulam Musthafa. Jilā al-Adhhān. Terj. Ahmad Najib Mahfudz. Yogyakarta: Ash-Shaff, 1997, Cet. II.

Hidayat, Komaruddin. Memahami Bahasa Agama; Sebuah Kajian Hermeneutik. Jakarta: Paramadina, 1996.

Jabir, Husein bin Muslim Ali. Membentuk Jama'ah Muslimin. Jakarta: Gema Insani Press, 1992. Cet. II.

Al-Jailani, Muhammad bin 'Aqil 'Abdullah Dahlan. Mudzakarah 6 Sifat. Bintaro: Yayasan Hayatur Rasul, tt.

Al-Kandahlawi, Maulana Muhammad Yusuf. Muntakhab Ahāäith. Yogyakarta: Penerbit Ash-Shaf, 2007.

Al-Kandahlawi, Maulana Muhammad Zakariya. Himpunan Fadhilah Amal Bandung: Pustaka Ramadhan, tt. 
Khan, Maulana Wahiduddin. Tabligh Movement. Delhi: Islamic Center, 1994.

Al-Khūli Amīn. Manāhij Tajdid fỉ al-Naḥw wa al-Balāghah wa al-Tafsìr wa alAdab. Kairo: Dār al-Ma'rifah, 1961.

Mansur, Maulana Muhammad. Masturah: Usaha Dakwah di Kalangan Wanita. Bandung: Pustaka Ramadhan, 2001.

Masud, Muhammad Khalid (ed.). Travellers in Faith; Studies of the Tablighi Jama'at as a Transnational Islamic Movement for Faith Renewal. Leiden: Brill, 2000.

Meuleman, Johan (ed.). Islam In the Era of Glabalization; Muslim Attitudes towards Modernity and Identity. New York: Routledge, 2002.

Muslim Ibn al-Hajjaj. Șahịḥ Muslim, Juz II.

al-Nadwi, Ali. Life and Mission of Maulana Mohammad Ilyas. Lucknow: Academy of Islamic Research and Publication, 1983.

al-Nadwi, Abu Hasan Ali. Maulana Muhammad Ilyas. Terj. Masrokhan Ahmad. Yogyakarta: Ash Shaff, 1990. Cet. II

Razak, Yusron. "Jamaah Tabligh: Ajaran dan Dakwahnya." Disertasi UIN Jakarta: 2008.

Shahab, Nadhr M. Ishak. Khurüj fỉ Sabìlillāh. Bandung: Pustaka Billah, tt.

Syilbi, Sa'ad bin Ibrahim., Dalil-dalil Dakwah dan Tabligh. Bandung: Pustaka Ramadhan, 2004. 